\title{
Emphases of Parenting in the Light of Three Comparison Groups
}

\author{
Ella Laukkanen ${ }^{1}$, Sanna Karppinen ${ }^{1}$, Kaarina Määttä ${ }^{1} \&$ Satu Uusiautti ${ }^{1}$ \\ ${ }^{1}$ Faculty of Education, University of Lapland, Rovaniemi, Finland \\ Correspondence: Kaarina Määttä, Faculty of Education, University of Lapland, Rovaniemi, P.O. Box 122, 96101 \\ Rovaniemi, Finland. Tel: 358-400-696-480. E-mail: Kaarina.Maatta@ulapland.fi
}

Received: January 3, 2014 Accepted: February 10, 2014 Online Published: February 24, 2014

doi:10.5539/ies.v7n3p67

URL: http://dx.doi.org/10.5539/ies.v7n3p67

\begin{abstract}
Parenthood is a phenomenon that is not easy to research. This study analyzed the emphases of parenting in the light of three comparison groups. The research was grounded on Bradley's (2007) theory of six fundamental parenting tasks. This was a case study focusing in one second-grade classroom. The teacher, 18 parents, and 19 pupils were recruited in the study. The data comprised three sets as well: questionnaires for parents, pupils' essays and drawings, and the teacher interview. The data were collected in 2012. The analysis represented theory-led content analysis. The results showed that the emphases of parenting tasks varied among the comparison groups and the emphases are illustrated in a triangle showing the variation. The most important task was the present parent who loves the children, and discusses and gives time for them. The role of parental love as the fundamental basis of parenting is discussed.
\end{abstract}

Keywords: parenthood, upbringing, education, parenting, family, parent-child relationship

\section{Introduction: Perspectives on Upbringing and Parenthood}

Every one of us has some experiences of parenting. Parenthood is also a very personal experience because everyone does parenting in his or her own way and has unique experiences of parenthood. Thus, parenthood does not only involve quite powerful and sensitive opinions, but also includes responsibilities that are provided by national laws and the international agreement on children's rights (United Nations, 1989).

This study focused on parenthood from the points of view of parents, children, and teachers contributing a new perspective on parenthood research. The study was strongly theory-led: the analysis was based on Bradley's (2007) theory of six fundamental tasks of parenting. As the conclusion, the foci of parenthood are illustrated and further discussed.

The perception of parenthood is the way of seeing what makes a parent and what are the responsibilities and rights in parenting (Austin, 2007). Roles are a pertinent part of parenthood, and commonly, parenthood is seen as a way of being a father and a mother in order to help and raise the child to grow and develop (Määttä \& Uusiautti, 2012a, 2012b; Leinonen, 2004). In addition, permanence is one dimension of parenthood. Not only is it a common knowledge, but also the family law says that a parent is a person who takes care of a child and gives preference to the child's needs not just for a day but for a longer period of time (Alstott, 2004). Kristeri (2002) defines parenthood as a growth process referring to the fact that a parent also develops all the time. Therefore, there is not any absolute definition of parenthood but merely it is a complex and multidimensional process defined also by the child's developmental phases and personal characteristics (Crnic \& Low, 2002).

Parenthood is also connected to the concept of a family. During the past decades, the idea of a family has changed considerably, and the definition is not as straightforward today as it used to be (Matinlompolo, 2007). Consanguinity does not solely define a family, but nowadays it can be more relevant to consider family similar to a life span, constructing through events in life (Jallinoja, 2000).

Many parenting studies have focused on stress and other modern phenomena, such as hurry, efficiency expectations, and unstable relationships (Crnic \& Low, 2002) that do not only affect parents but also children (Huhtanen, 2007). In addition, the internet and media influence family life and upbringing (Deater-Deckard, 2004; Wilenius, 2002) — and the influence is not always a positive one (Lämsä, 2009; Uusikylä, 2006).

In order to support children's well-being in a best possible way, responsibility of upbringing and education is shared between parents and professional educators (Huhtanen, 2007; Tilus, 2004). Interaction, partnership, and 
equal conversation are of primary importance when talking about the educational partnership between a teacher and a parent (Cantell, 2011). The school and teachers have plenty of opportunities to enhance children's well-being but the influence can also be negative (Tilus, 2004). Although home-school partnership is to share the responsibility, parents can perceive the relationship threatening. As the institutional education happens with or without the parent, from the parent's point of view, his or her role in raising the child has diminished (Alasuutari, 2003).

The purpose of education partnership between home and school is to support children's development and growth and enable possible early intervention (Cantell, 2011; Hujala et al., 2009). This partnership pursues creating a holistic picture and interpretation of the child's behavior. This requires adults' genuine interest and their ability to communicate with each other (Huhtanen, 2007; Whitmarsh, 2011).

\section{Holistic Parenthood}

The latest research has emphasized parenthood as entity instead of separate parenting actions (Perälä-Littunen, 2004). In the 1960s' psychological research, Baumrind introduced a concept of parenting style referring to the holistic parenting and parenthood. Three styles were distinguished: authoritarian, authoritative, and permissive (Baumrind, 1989). Authoritative parenting is based on meeting the child's needs, setting limits, acting as the authority, democracy, and supporting the child's independency (see also Määttä \& Uusiautti, 2012a; Valkonen, 2006).

Parenthood as a concept and a phenomenon is wide and various theories have attempted to divide parenthood into certain areas. For example, Collins, Madsen, and Susman-Stillman (2002) have presented contents of basic parenting tasks: (1) controlling the child's behavior; (2) supporting the child's sense of responsibility and fending for oneself; (3) promoting the emergence of positive relationships in the child's life; and (4) enabling and supporting outer-family experiences. Success in controlling the child's behavior depends on parents' ability to talk about their expectations for, give feedback to, and supervise the child. As the child grows, the control diminishes and the child has more responsibility over his or her behavior.

According to Steinberg and Silk (2002), the primary dimensions of parenting relationship are harmony, autonomy, and ability to solve conflicts. Harmony refers to the warmth of the relationship, expression of feelings, and engagement whereas autonomy means the level of controlling the offspring. The latter dimension refers to the nature of the relationship and whether it is merely continuing or disinclined.

From the point of view of positive psychology, Seligman (2002) has named eight principles of parenthood. These include creating safe attachment through immediate, constant care, teaching the significance of acts and its relation to control, and continuity in using the words "yes" and "no". Parents should also compliment and punish the child in a well-balanced way and when justified. Sibling rivalry can be prevented by emphasizing the child's individuality and strengths. Seligman argues that the golden moments of going to bed should be valuable for the parent and used for discussing with the child. Agreements should be made in a good spirit in order to reinforce positive action. The parent should concentrate on positive achievements and development of strengths (Seligman, 2002). These principles have emphasis on balance and presence - like many other theories do too.

The holistic approach to parenthood is also evident in perceptions of what is good parenthood. For example, Perälä-Littunen's (2004) study of good motherhood from the adults' perspective brought up care, positive influence on the child's development, and meeting the child's needs. Likewise, Hietanen et al.'s (2012) study of good fatherhood narrated by children covered similar kinds of elements. In this study, seven types of good fathers were distinguished: (1) the active father spending plenty of time with children, (2) the caring and nurturing father, (3) the disciplinarian father, (4) the exemplary father, (5) the father in a respected position, (6) the father participating in household work, and (7) the fair father. According to Valkonen's (2006) study, not just one dimension of a good parenting is enough but the overall perception of good parenthood is a sum of many elements.

Bradley's (2007) theory of six basic tasks of parenthood includes various dimensions that belong to parenting (Table 1). The theory can also be used for supporting the life of families in challenging circumstances, and to show how to support children's healthy and safe development. The tasks presented in the theory are primary tasks, and because of the fundamental nature of the theory, it was also selected in this study (see Bradley, 2007; see also Holden, 2010; Holden, Vittrup, \& Rosen, 2010). 
Table 1. Fundamental tasks of parenting (Bradley 2007, p. 109)

\begin{tabular}{|c|c|}
\hline \multicolumn{2}{|c|}{ Safety/sustenance } \\
\hline Household structure \& arrangements & Access to food \\
\hline Neighborhood surroundings & Access to health care \\
\hline Exposure to teratogens & Protection from imminent harm \\
\hline \multicolumn{2}{|c|}{ Socio-emotional support } \\
\hline Responsiveness \& sensitivity & Warmth \& affirmation \\
\hline Discipline practices & Negativity/intrusiveness Assistance with \\
\hline Expectations & emotion regulation \\
\hline Positive affectivity & Encouragement \& guidance \\
\hline Communication & Modeling of mature behavior \\
\hline \multicolumn{2}{|c|}{ Stimulation (instruction) } \\
\hline $\begin{array}{l}\text { Toys \& learning materials } \\
\text { Direct instruction }\end{array}$ & $\begin{array}{c}\text { Provision for lessons Culturally enriching } \\
\text { experiences }\end{array}$ \\
\hline Language \& literacy exposure & Encouragement of achievement \\
\hline Exposure to media & Recreational activities \\
\hline Coaching & \\
\hline \multicolumn{2}{|c|}{ Surveillance (monitoring) } \\
\hline Proximity/visual contact & Data gathering from child \\
\hline Direct data gathering about child & Indirect data gathering about child \\
\hline \multicolumn{2}{|c|}{ Structure } \\
\hline Family routines & Rituals \\
\hline Organization of activities & Time management Scaffolding \\
\hline \multicolumn{2}{|l|}{ Organization of physical environment } \\
\hline \multicolumn{2}{|c|}{ Social connectedness } \\
\hline Relatives \& friends & Non-familial social networks \\
\hline Community institutions & Work connections \\
\hline Child's peer networks & \\
\hline
\end{tabular}

\section{Method}

This study compared perceptions of the emphases of parenthood. The study represents a case study in which parents', children's, and a teacher's perceptions of parenthood were contrasted. On the one hand, the purpose was to analyze the shared conception of parenthood, and on the other hand, also how the conceptions differed from each other. Bradley's (2007) theory was used as a theoretical framework.

The following research questions were set for the study:

(1) How do parents, children, and the teacher describe parenthood?

(2) What similarities and differences do the descriptions of parenthood have?

The study was conducted in a middle-size school in northern Finland, among second-graders. The participants of the research were 18 parents, 19 pupils, and the teacher of the grade. Parents (13 women and 5 men) were 30-50 years old. Majority of the parents had graduated from higher education and relatively many $(n=5)$ of them worked in the field of education. Most of the participants represented nuclear families with parents and their common children. Ten of the pupils were girls, and nine boys. The grade had altogether 24 pupils, but three of them were not allowed to participate in the study and two were absent from school when the data collection took place. The teacher had worked as a teacher for 25 years of which the last 15 years among grades 1-3.

The data were collected with various methods. The methods were selected based on the participant groups' abilities and availability, as it was obvious that small second-graders could not be interviewed with similar questions than adult participants (see Uusiautti \& Määttä, 2013). Therefore, children were addressed with methods suitable to their age. The teacher was interviewed, but when it came to parents, it was more difficult to arrange interviews. Therefore, parents were approached with an electric questionnaire that was sent them by email. This was considered a good way of reaching parents for research purposes. The parents were informed of the research in a parents' meeting at school and they were also given the permission forms concerning their children's participation in the research. The questionnaire included both open questions that parents could answer freely and multiple-choice questions. Open questions concerned for example the values, rules, and 
punishments used at home. Structured questions covered the evaluations of parents' support and time spent together (e.g., How much do you support your child with the following issues related to school? Evaluate with the scale from 1 to 5 , one being very little and 5 very much). The questionnaire included 24 questions including background questions.

There are many ways of bringing out children's voices in research (Uusiautti \& Määttä, 2013). In this study, pupils were asked to write an essay and draw about what they do with parents. The title of the essay was "My parents". The pupils were also given auxiliary questions (e.g., What do you do together with your parents?; What is the best/worst in your parents?; How do your parents help you?; etc.) to help their writing. The drawing was supposed to illustrate what the pupils do with their parents. On the reverse side of the paper, the pupils were asked to write about the picture.

The teacher was interviewed with a semi-structured theme interview. The interview questions were designed beforehand but the sequence could be changed during the interview. The interview took place at the end of the semester when the busy school year was over but the summer holiday had not yet begun. The teacher was allowed to familiarize with the interview questions beforehand. The questions covered various sides of parenthood (e.g., In your opinion, what are parents' responsibilities from the pupil's point of view?; What is bad parenting in your opinion? Please, provide an example; etc.) and how parents could support children's everyday life.

All data were analyzed with content analysis, each set of data with a suitable application of it (Tuomi \& Sarajärvi, 2009). The qualitative content analysis was theory led as Bradley's (2007) six categories were used as the main categories. On the one hand, it provided a good basis for categorizing three various sets of data, making their analyses comparable. On the other hand, new issues could emerge within the categories and the existing theory of parenting could be evaluated through the results.

The parent questionnaires were analyzed qualitatively although they included also quantitative data. However, it was more important to study the nature of parenting and therefore the emphasis was on the expressions and emphases in the participants' answers. This was how the teacher interview was analyzed, too. After writing the transcript, the simplified expressions formed categories that were placed into the predetermined six categories.

The pupils' essays and drawings were also dissected from the point of view of Bradley's parenting tasks. Content analysis of drawings can be divided into four main phases: selection of pictures, categorization, coding, and analysis (Rose, 2007). In practice, the pupils' drawings were divided into the six categories but instead of counting the incidence of parenting tasks, we analyzed what each drawing tells about the theme. The analysis of drawings had several codes with which each drawing was analyzed. All codes were written carefully to guarantee systematic analysis of every drawing. For example, it could be analyzed whether the doing illustrated in the drawing could be seen as mutual or shared activity with the parents or not. Pupils' explanations on the back of the drawing helped considerably in figuring out how to interpret the drawings. The analysis of pupils' essays followed the same idea and expressions describing each category were gleaned from them.

The results section included excerpts from the data. Parents are referred with a number and $\mathrm{F}$ "Female" and $\mathrm{M}$ "Male", and children with a number and letter "C". Quotations of the teacher interview have been marked without a number. The data excerpts are to illustrate the data and support the researchers' the interpretations.

\section{Results}

The research results will be presented following Bradley's (2007) theory of the six fundamental tasks of parenting. The themes are therefore theory-bound but the results show the case-study-specific emphases.

The task providing safety/sustenance was strongly emphasized in the viewpoints of each comparison group. More than anything, participants reported sufficient nourishment, exercising, and rest as the key parenting tasks. The teacher stressed all these three very clearly as the teacher thought that they ensure the safe basic life for children.

"All basic things there (at home): sleep rhythm, dining, sufficient nourishment, and exercising. Having them all in balance."

Also parents valued these three basic needs:

"(The basic values are) sleep, food, exercise" (F8)

However, parents' had slightly different emphases between these three. Most importantly they talked about sufficient sleep, and providing food came second. Instead, exercising and sports were named as areas in which parents had less control although they mentioned that they use to exercise with their children. Actually, this was 
the most important form of doing things together with their children. Thus, it seemed that parents do not want to decide their children's sportive hobbies as such but do exercise with their children.

Children, on the other hand, reported that providing food was the most salient parenting task. Likewise, children told that they exercise with their parents. Spending time outdoors and exercising was also a typical theme in children's drawings. Children did not mention about sufficient sleep in their answers.

According to this case study, socio-emotional support as a parenting task can be described by one word: the word is love. Parental love was a combining factor in the answers of all three research groups. Naturally, parental love is a part of all tasks of parenting but in the data it seemed have more emphasis when considering the socio-emotional support. The teacher reflected love at an abstract level but the parents' answers had more concrete examples of how love is manifested as action at home. Children's answer described love as their positive position as the receivers of parental love.

The teacher emphasized parents' unconditional love toward their children in all parenting. Parental love should be the fundamental force whether the question was about setting limits, punishing, or handling of difficult feelings. When asking the teacher to name three most important values related to parenthood the teacher mentioned unconditional love the first. Many contents and tasks of parenting can be realized through sincere love.

"Well, the first one is probably to love the child genuinely and sincerely, and that means attention and care for the child. It shows, if you love the child truly, it includes so much."

Not surprisingly parents considered love and closeness important. Some of them regarded these as the most valuable.

"Paying attention to others, love." (F15)

In addition, parents reported that they tend to show affection to their children openly:

"I would like that my children felt that they can come to dad's and mom's lap always, both in good and bad days. Kisses, affection, laugh, and sincerity are things that I would like to be manifested in my family." (M16)

The children's writings confirmed that love, positive words, and other favorable experiences are meaningful and feel good. The children told that these things are the best in parents. Joy and happiness as the outcome of closeness were evident in children's drawings, too.

"What is the best in my parents, is that they like me." (C19)

The only conflicting result in the data concerned the setting of limits and punishments. Parents used considerably time to describe the rules and punishing methods they had at home while children thought that rules and punishments set by parents were the worst things in parenting. In all other issues, children clearly either confirmed positively or described neutrally their parents' action. Rules and punishments were, however, seen negatively.

On the other hand, it is worth noticing that punishments are to teach children because they have done something wrong, and they are not even supposed to feel nice. Children's negative experiences therefore support the parents' answers: they have been guided and punished by parents.

Stimulation (instruction) as a part of parenting was strongly connected with school. Parents, children, and the teacher emphasized quite different things when it came to support of children's studies. Parents considered that it is important that children enjoy going to school and that they care of that children do their homework. Otherwise, parents did not intervene in their children's school life or told that they are relatively little interested in it. However, children reported — which was quite the opposite of what parents told - that parents help them a lot with homework.

"The best thing is that they (parents) help with homework." (C4)

"My parents help me if I have difficult homework." (C9)

Some children did certainly mention that they need more help with homework. The teacher's perspective to parents' support focused merely on the general support a child needs and on encouragement. The teacher brought up the fact that parents' interest, encouragement, and support correlate to children's academic success and motivation at school.

"Well, at least I think it is obvious that if the parents are interested in their child's school going, they want to support and spur, and this keeps up the motivation and the school success will then reach the level that is possible to that particular child. Maybe even better than one could predict." 
Parents and children mentioned also other stimuli of which the most salient were various hobbies. Children described how parents take them to hobbies while parents emphasized hobbies as way of doing things together.

Surveillance as a parenting task includes monitoring of the child's doings and development. Proper surveillance necessitates communication with the child which became the most important element of surveillance in this study. Parents, children, and the teacher all considered mutual discussions and spending time together significant. Communication and shared time partly relate to the socio-emotional support, and it seems that it is challenging to classify strictly all the tasks parenting involves. Likewise, the teacher told that for children, already the parents being available and arranging time to spend with children, is important. They are the ways of maintaining the connection in addition to communicating and listening to the child.

"Being present in the child's everyday life and close all the time, available, and have time, listen to the child. So that the interaction with the child becomes genuine. The child understands that he or she is loved and heard."

The teacher also told that when listening to a child, the atmosphere should be safe. Indeed the teacher had advised the parents to have a peaceful moment with a child every evening before bed time. The moment can be used for talking about the happenings of the day. The parents' answers showed that they actually followed this advice quite well because they reported how they arrange time for discussing with their children. Parents also talked about other discussions they have with their children during the day, everyday discussions that occur naturally.

"I discuss how the day has gone." (F1)

"I talk with the child daily.... Our connection is quite tight every single day." (F5)

Children's writings and drawings highlighted the meaning of listening, too. Children described communication with their parents with speech bubbles that included short communications. Writings also had mentions about the lack of communication and listening.

"It sticks when my parents do not listen to me." (C13)

On the other hand, children told that the time spent with parents was the best. Especially, they loved toying and playing with parents.

"The best in my parents is when they play with me." (C18)

"The best in my parents is that they are outdoors with me." (C19)

Structure was manifested somewhat similarly as safety as a parenting task in these data. Sleep, nourishment, and exercising create routines and a certain structure for daily life. The teacher also brought up how these tasks must occur as a matter of routine. The way these two areas of parenting tasks are interconnected means that the fulfilment of physical needs is a central issue in the everyday life, and thus forms a salient structure in the family life.

Parents also highlighted separately that routines and a regular rhythm of life are extremely important and valuable. The teacher stressed the child's point of view: the child does well when the basic everyday life goes well meaning that the child has a safe framework and routines at home. In other words, the parents has to take care that the everyday life has a functional structure.

In this study, social connectedness was mainly seen from the points of view of school and hobbies. According to the data, it became evident that parents help their children to maintain social relationships, especially when it comes to peer relationships. Parents told that they help their children to communicate with their friends and that they discuss peer relationships with their children. In addition, parents reported that they encourage their children if they need it in their relationships with other children.

"(Do you help your child in something?) Communication with friends." (F3)

"Our second-grader has needed help mostly with...things related to social skills. When the child is naturally shy, plenty of encouragement is needed." (M16)

Children also expressed their parents' support in social relationships. They wrote that they need parents' help in conflicts with friends, and usually they got help. This is how parents foster children's social connectedness.

"Well, my parents help me if I have e.g. some arguments." (17)

Especially, the teacher highlighted the significance of the development of social skills in children's social relationships. In the teacher's opinion, it the parents' task to monitor whether the child has friends or not, and to guide and support the child in peer relationships. All children do not necessarily talk much about school at home 
and therefore parents need the skill of reading between the lines in order to find out the child's friendship situation at school.

\section{Discussion}

The research results show that parents, children, and the teacher had more or less similar understanding about parenting tasks. They pointed out similar issues and areas of parenting. On the other hand, there were tasks that could be emphasized by only two participant groups, one of the groups having a different opinion or not mentioning the task. Thus, the emphases of the importance of different parenting tasks could differ.

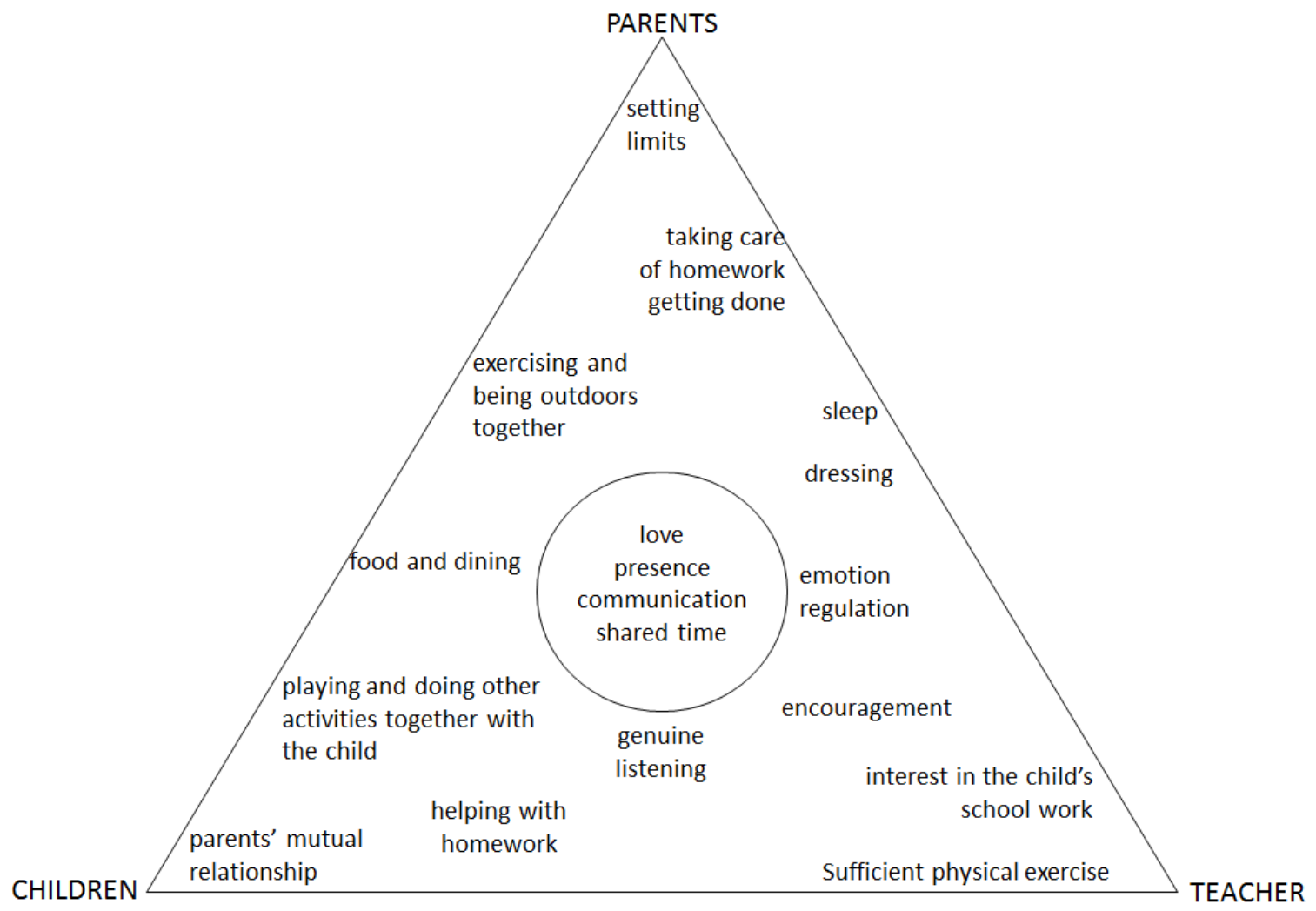

Figure 1. Emphases of parenting in the light of three comparison groups

Figure 1 illustrates how the groups in this case study understood parenting. Each apex of the triangle refers to one comparison group. Emphases included inside the triangle describe how important each parenting task was from the point of view of the comparison group. The closer the task appears to an apex, the more important the task was in the emphases of the group. The center of the triangle includes parenting task that every group considered important.

The strongest emphasis was on providing nourishment and socio-emotional support. These can also be found from Maslow's (1987) hierarchy of needs according to which the basic needs are physiological by nature (e.g., food and sleep). According to Bornstein (2001), parents have to fulfil children's biological, physical, and health-related needs.

The comparison groups also stressed the importance of a parent being present and loving through discussing and giving time. These parenting tasks are located in the areas of socio-emotional and surveillance (Bradley, 2007). The need of bonding and the sense of togetherness follow the physiological needs in the hierarchy (Maslow, 1987). Bradley does not make any hierarchical categorizations but it can be interpreted that the shared emphasis among the participants of this study has an important role in parenting.

Although the categorization of basic parenting tasks was used for analyzing the research results, it seemed sometimes difficult to distinguish categories from each other. For example, the presence of a parent and time spent together with a child was repeatedly referred to in the answers. However, these tasks could be located in many categories as they could provide safely, stimulation, or socio-emotional support. Indeed, the parent's presence has 
had plenty of emphasis on several theories of parenthood (e.g., Helminen \& Iso-Heiniemi, 1999; Pulkkinen, 1994; Seligman, 2002). Moreover, the time parents spend with their child is related to responsible parenting (e.g., Arendell, 1997; Beck-Gernheim, 1992; Böök \& Perälä-Hiltunen, 2010) and make a significant part of studies on good parenthood (e.g., Sheridan \& Burt, 2009; Valkonen, 2006).

As parenthood as a phenomenon appeared holistic rather than a combination of carefully defined categories, it might be relevant to ask whether it is even necessary to define the tasks of parenting - or whether it is even possible. For example, Bradley names parental love as a part of the socio-emotional task of parenting. But can love, given the comprehensive nature of it, be even lumped together within one category or distinguish it from other categories (see also Bryant, Chadwick, \& Kluwe, 2011)? Moreover, what parents do affects the child comprehensively and all the time, some actions more than others. In addition, parents' actions are connected with their previous and future action, and thus form a continuing and holistic process.

\section{Conclusion}

Parenthood makes a challenging and wide research theme. In addition, it is extremely personal in nature. Research on parenthood has been criticized for its superficiality: studies cannot reach the profound nature of parenthood or causalities. Data collected within a short period of time cannot cover the whole essence of parenthood, and too excessive generalizations are being made (Aunola, 2005). Still, by careful planning and research designs, it is possible to open the curtain and combine various viewpoints to the phenomenon. The main contribution of this study probably lies in the way of obtaining personalized data from three closely interrelated groups, and analyzing the data with a predetermined structure.

Still, the fact that parenthood is personally experienced sets special conditions for research. Although various types of triangulation can be applied in research, the true diversity of data can be questioned. For example in this study, the parents who decided to participate in the research seemed to represent certain family types and professions. Most of the participants lived in nuclear families, were highly educated, and worked in the field of education. Most likely, their backgrounds had an impact to the results. One can also ask whether the research theme was too sensitive: was it even possible that all parents or family types could have participated in this kind of research.

In addition, the results can be criticized for being too idealistic and far away from the actual everyday life. For example, the teacher's answers could represent merely a professional educator's opinions than the teacher's real opinion on the parents of the pupils in the classroom. What about parents? Did they answer truthfully or did they talk about ideal parenthood? The realization of parenthood was not studied in this research, and on the other hand, absolute parenthood cannot be figured out comprehensively. Maybe it is the children who answered the most openly and from the practical perspective. However, especially the points that straddled these three sets of data can be seen valuable and reliable - the core of findings.

In all despite the challenges of parenthood research, the purpose was to find out how the participants would describe parenthood when making them consciously discuss the phenomenon. Conscious parenthood helps parents evaluate and thus develop their parenting skills. This is because the awareness of the connection between one's mental states and emotional regulation and one's action forms the basis of mature and reflective parenting (Fonagy et al., 1991). "Reflective functioning refers to the capacity not only to recognize mental states, but to link mental states to behavior in meaningful and accurate", concludes Slades (2005, p. 275). In this study also, the purpose was to reflect upon parenting tasks from various points of view. By bringing out the perspective of multiple sides - the teacher, parents, and children - it is possible to show how differently parenthood can be seen and how widely parenting tasks expand. Most importantly, the study showed that parental love at the heart of parenting cannot necessarily be categorized under just one category of parenting tasks but merely we want to think it as the fundamental basis of parenthood. Uusiautti and Määttä (2011; see also Määttä \& Uusiautti, 2013) have defined love as a combination of three areas: emotions, acts, and knowledge and skills. These three areas can be seen in reflective parenting as well. Not only is parenting a systematic performance of certain practical tasks but also a matter of creating the sense of being accepted and the sense of togetherness. Genuine care and concern over the child's feelings and doings teach the child emotional regulation and that he or she is wanted and accepted as he or she is. Parenting also requires certain love-based skills, such as interaction skills and ability to make decisions and set rules, and to stick to them.

Our perspective considers parents as models of self-control, social skills, engagement in learning, and healthy lifestyles (Uusiautti, K. Määttä, \& M. Määttä, 2013; see also Hubbs-Tait, 2008; Nijhof \& Engels, 2007; Veríssimo et al., 2011), and providers of the sense of "worthy of love" in children (Lawrence, 2001). The purpose is not to set pressure to parents and demand ideal parenting from all. Parents are different and children 
are too. Merely, the purpose is to analyze and specify important elements of parenthood that can be enhanced and materialized through parents' action.

\section{References}

Alasuutari, M. (2003). Kuka lasta kasvattaa? [Who is raising the child?] Tampere: Gaudeamus.

Alstott, A. (2004). No exit: What parents owe their children and what society owes parents? Cary, NC: Oxford University Press.

Arendell, T. (1997). Contemporary parenting. Challenges and issues. Understanding families. London: Sage.

Aunola, K. (2005). Kasvatus ja vanhemmuus: Tutkimuksen traditiot ja haasteet [Upbringing and parenting: Research traditions and challenges]. Psykologia, 40(4), 356-369.

Austin, M. (2007). Conceptions of parenthood: Ethics and the family. Abingdon: Ashgate Publishing.

Baumrind, D. (1989). Rearing competent children. In W. Damon (Ed.), Child development today and tomorrow (pp. 349-376). San Francisco, CA: Jossey-Bass.

Beck-Gernheim, E. (1992). Everything for the child-For better or worse? In U. Björnberg (Ed.), European parents in the 1990s. Contradictions and comparisons (pp. 59-82). London: Transaction.

Böök, M.-L., \& Perälä-Littunen, S. (2010). Vastuullisen vanhemman velvoitteet [The obligations of a responsible parent]. Kasvatus, 41(1), 41-52.

Bornstein, M. H. (2001). Parenting: Science and practice. Parenting: Science and Practice, 1(1-2), 1-4.

Bradley, R. H. (2007). Parenting in the breach. How parents help children cope with developmentally challenging circumstances. Parenting: Science and Practice, 7(2), 99-148.

Bryant, F. B., Chadwick, E. D., \& Kluwe, K. (2011). Understanding the processes that regulate positive emotional experience: Unsolved problems and future directions for theory and research on savoring. International Journal of Well-being, 1(1), 107-126. http://dx.doi.org/10.5502/ijw.v1i1.18

Cantell, H. (2011). Vaikeat vanhemmat, kurjat kollegat? Ratkaiseva vuorovaikutus aikuisten kesken [Difficult parents, nasty colleagues? The decisive interaction between the adults]. Jyväskylä: PS-kustannus.

Collins, W. A., Madsen, S. D., \& Susman-Stillman, A. (2002). Parenting during middle childhood. In M. H. Bornstein (Ed.), Handbook of parenting (Vol. 1, pp. 73-101). Mahwah, NJ: Erlbaum.

Crnic, K., \& Low, C. (2002). Everyday stresses and parenting. In M. H. Bornstein (Ed.), Handbook of parenting (Vol. 5, pp. 243-267). Mahwah, NJ: Erlbaum.

Deater-Deckard, K. (2004). Parenting stress. New Haven, NJ: Yale University Press.

Fonagy, P., Steele, M., Moran, G., Steele, H., \& Higgitt, A. (1991). The capacity for understanding mental states: The reflective self in parent and child and its significance for security of attachment. Infant Mental Health Journal, 13(3), 200-216.

Helminen, M.-L., \& Iso-Heiniemi, M. (1999). Vanhemmuuden roolikartta. Käyttäjän opas [The role map of parenting. The use manual]. Helsinki: Suomen kuntaliitto.

Hietanen, R., Määttä, K., \& Uusiautti, S. (2013). 'Virtuoso ideal daddy': Finnish children's perceptions of good fatherhood. Early Child Development and Care, 183(12), 1827-1840. http://dx.doi.org/10.1080/03004430.2012.755965

Holden, G. W. (2010). Parenting. A dynamic perspective. Thousand Oaks, CA: Sage.

Holden, G. W., Vittrup, B., \& Rosen, L. H. (2011). Families, parenting, and discipline. In M. K. Underwood, \& L. H. Rosen (Eds.), Social development. Relationships in infancy, childhood, and adolescence (pp. 127-152). New York, NY: Guilford Press.

Hubbs-Tait, L., Kennedy, T. S., Page, M. C., Topham, G. L., \& Harrist, A. W. (2008). Parental feeding practices predict authoritative, authoritarian, and permissive parenting styles. Journal of the American Dietetic Association, 108, 1154-1161. http://dx.doi.org/10.1016/j.ada.2008.04.008

Huhtanen, K. (2007). Kun huoli herää. Varhainen puuttuminen koulussa [When you start worrying. Early intervention at school]. Jyväskylä: PS-kustannus.

Hujala, E., Turja, L., Gaspar, M. F., Veisson, M., \& Waniganayake, M. (2009). Perspectives of early childhood teachers on parent-teacher partnerships in five European countries. European Early Childhood Education 
Research Journal, 17(1), 57-76.

Jallinoja, R. (2000). Perheen aika [Time for the family]. Helsinki: Otava.

Kristeri, I. (2002). Vahvaan vanhemmuuteen [Toward strong parenthood]. Helsinki: Kirjapaja.

Lämsä, A.-L. (2009). Yhteiskunnan muutos ja elämän riskit [Societal change and life risks]. In A.-L. Lämsä (Ed.), Mun on paha olla. Näkökulmia lasten ja nuorten psyykkiseen hyvinvointiin [I feel bad. VIews on the mental well-being in children and the youth] (pp. 21-32). Jyväskylä: PS-kustannus.

Lawrence, M. M. (2001). The roots of love and commitment in childhood. Journal of Religion and Health, 40(1), 61-70.

Leinonen, J. (2004). Vanhemmuus lapsen kasvuympäristön osana [Parenthood as the part of a children's growing environment]. Psykologia, 39(3), 176-195.

Määttä, K., \& Uusiautti, S. (2012a). How to raise children to be good people? Analytic Teaching and Philosophical Praxis, 33(1), 83-91.

Määttä, K., \& Uusiautti, S. (2012b). Parental love-Irreplaceable for children's well-being. Global Journal of Human Social Sciences, 12(10), 1-8.

Määttä, K., \& Uusiautti, S. (2013). Many faces of love. Boston/Rotterdam/Taipei: Sense Publishers.

Maslow, A. H. (1987). Motivation and personality. New York, NY: Harper \& Row.

Matinlompolo, U. (2007). Vanhemmuus ei ole ammatti [Parenthood is not a profession]. In K. Määttä (Ed.), Helposti särkyvää. Nuoren kasvun turvaaminen [Fragile. Securing the development of the youth] (pp. 104-117). Helsinki: Kirjapaja.

Nijhof, K. S., \& Engels, R. C. (2007). Parenting styles, coping strategies, and the expression of homesickness. Journal of Adolescence, 30, 709-720. http://dx.doi.org/10.1016/j.adolescence.2006.11.009

Perälä-Littunen, S. (2004). Cultural images of a good mother and a good father in three generations. Jyväskylä: University of Jyväskylä.

Poikolainen, J. (2002). Kasvatustietoisuuden ulottuvuuksia. Vanhempien käsityksiä kasvatuksesta ja vanhemmuudesta [Dimensions of educational awareness. Parents' perceptions of upbringing and parenthood]. Helsinki: University Press.

Pulkkinen, L. (1994). Millaista lastenkasvatusta nykytutkimus suosittelee? [What kind of child rearing is recommended by the modern research?] In J. Virkki (Ed.), Ydinperheestä yksilöllistyviin perheisiin [From nuclear families to individualizing families] (pp. 26-45). Juva: Wsoy.

Rose, G. (2007). Visual methodologies: An introduction to the interpretation of visual materials. London: Sage.

Seligman, M. (2002). Authentic happiness. Using the new positive psychology to realize your potential for lasting fulfillment. New York, NY: Free Press.

Sheridan, S. M., \& Burt, J. D. (2009). Family-centered positive psychology. In S. J. Lopez, \& C. R. Snyder (Eds.), Oxford handbook of positive psychology (pp. 551-559). Oxford: Oxford University Press.

Slade, A. (2005). Parental reflective functioning: An introduction. Attachment \& Human Development, 7(3), 269-281. http://dx.doi.org/10.1080/14616730500245906

Steinberg, L., \& Silk, J. S. (2002). Parenting adolescents. In M. H. Bornstein (Ed.), Handbook of parenting (Vol. 1, pp. 103-133). Mahwah, NJ: Erlbaum.

Tilus, P. (2004). Pelistä pois? Huolehtivan koulun haaste [Out of the game? The challenge of nurturing school]. Jyväskylä: PS-kustannus.

Tuomi, J., \& Sarajärvi, A. (2009). Laadullinen tutkimus ja sisällönanalyysi [Qualitative research and content analysis]. Helsinki: Tammi.

Uusiautti, S., \& Määttä, K. (2011). The ability to love-A virtue-based approach. British Journal of Educational Research, 2(1), 1-19.

Uusiautti, S., \& Määttä, K. (2013). Many dimensions of child research. In S. Uusiautti, \& K. Määttä (Eds.), How to study children? Methodological solutions of childhood research (pp. 11-28). Rovaniemi: Lapland University Press.

Uusiautti, S., Määttä, K., \& Määttä, M. (2013). Love-based practice in education. In M. A. Villas-Boas, R. 
Marques, \& P. Silva (Eds.), Families, schools, and communities: New trends for a future with equity (pp. 309-330). Porto: Caminhos Romanos.

Uusikylä, K. (2006). Hyvä, paha opettaja [Good, bad teacher]. Jyväskylä: Gummerus.

Valkonen, L. (2006). Millainen on hyvä äiti tai isä? Viides-ja kuudesluokkalaisten lasten vanhemmuuskäsitykset [What is a good mother or father like? Fifth- and sixth-graders' perceptions of parenthood]. Jyväskylä: University of Jyväskylä.

Veríssimo, M., Santos, A., Vaughn, B. E., Torres, N., Monteiro, L., \& Santos, O. (2011). Quality of attachment to father and mother and number of reciprocal friends. Early Child Development and Care, 181(1), 27-38.

Whitmarsh, J. (2011). Othered voices: Asylum-seeking mothers and early years education. European Early Childhood Education Research Journal, 19(4), 535-551. http://dx.doi.org/10.1080/1350293X.2011.623540

Wilenius, R. (2002). Miten käy lasten ja nuorten? Keskustelua ja filosofiaa kasvatuksesta [What will happen to children and the youth? Discussion about and philosophy of education]. Helsinki: Hakapaino.

\section{Copyrights}

Copyright for this article is retained by the author(s), with first publication rights granted to the journal.

This is an open-access article distributed under the terms and conditions of the Creative Commons Attribution license (http://creativecommons.org/licenses/by/3.0/). 